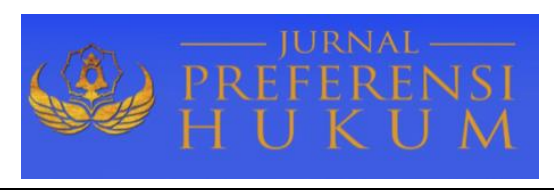

Jurnal Preferensi Hukum | ISSN: XXXX | E-ISSN: XXXX

Vol. 1, No. 2 - September 2020, Hal. 196-200| Available Online at https://www.ejournal.warmadewa.ac.id/index.php/juprehum

DOI: http://doi.org/10.22225/jph.v1i2.2408.196-200

\title{
PEMIDANAAN TERHADAP PELAKU TINDAK PIDANA KORUPSI MELALUI DOUBLE TRACK SYSTEM
}

\author{
Anak Agung Gede Budhi Warmana Putra, Simon Nahak, I Nyoman Gede Sugiartha \\ Fakultas Hukum Universitas Warmadewa, Denpasar-Bali, Indonesia
}

\begin{abstract}
Abstrak
Penelitian ini bertujuan untuk mencari efek jera bagi pelaku tindak pidana korupsi yang diberlakukan dengan konsep Double Track System. Sistem Jalur Ganda merepresentasikan sistem hukuman melalui dua jalur yaitu sanksi pidana dan pengobatan. Penelitian ini menggunakan metode hukum normatif. Sumber bahan hukum yang digunakan adalah bahan hukum primer yaitu peraturan perundang-undangan dan bahan hukum sekunder berupa teori-teori hukum. Permasalahan yang diteliti dalam penelitian ini adalah pengaturan hukum bagi pelaku tindak pidana korupsi dan sistem pidana terhadap pelanggarnya. Hasil penelitian menunjukkan bahwa tentang tindak pidana korupsi dan sanksi yang dijatuhkan kepada pelanggarnya diatur dalam Undang-Undang Nomor 31 Tahun 1999 Jo. Undang-Undang Nomor 20 Tahun 2001 tentang Penanggulangan Tindak Pidana Korupsi dan Sistem Hukuman dan Sistem Jalur Ganda terhadap pelaku tindak pidana korupsi. Pelanggar dikenakan sanksi kurungan.
\end{abstract}

Kata Kunci: Sistem Hukuman; Korupsi Tindak Pidana; Sistem Jalur Ganda

\begin{abstract}
This study aims to seek for deterrent effects for perpetrator of criminal acts of corruption that imposed with Double Track System concept. Double Track System represents the punishment system through two tracks which are criminal sanction and treatment. This study use normative law method. The resource of legal materials which used is primary legal material which is the legal rules and regulations and secondary legal material which is theories of law. The issues explored in this research are legal arrangement for offenders of criminal acts of corruption and punishment system against the offenders. The results showed that about the criminal acts of corruption and sanctions imposed on the offenders are set forth in Act No. 31 of 1999 Jo. Act No. 20 of 2001 about Decrement of Criminal Acts of Corruption and Punishment System and Double Track System against the perpetrators of criminal acts of corruption. The offenders are imposed imprisonment sanctions.
\end{abstract}

Keywords: Punishment System; Criminal Offense Corruption; Double Track System

\section{PENDAHULUAN}

Kejahatan korupsi yang telah terjadi selama ini seakan sudah mengakar kemana-mana, tidak hanya membuat rugi keuangan negara, tetapi juga merupakan pelanggaran terhadap hak-hak sosial dan ekonomi masyarakat secara luas. Bahkan dampak buruk yang disebabkan oleh korupsi tersebut timbul dalam berbagai bidang contohnya adalah pertumbuhan ekonomi dan investasi yang lambat, utang negara yang terus meningkat, harga layanan publik yang tinggi, fungsi pemerintah yang berjalan buruk, hilangnya kepercayaan publik terhadap kepemimpinan pemerintah, dan masih banyak lagi dampak yang bisa timbul akibat dari kejahatan korupsi tersebut. Berdasarkan dampak buruk dari kejahatan korupsi tersebut maka upaya pencegahan sekaligus pemberantasan yang dilakukan secara berkelanjutan guna menumbuhkan kesadaran dan sikap masyarakat yang anti korupsi (Syamsuddin, 2011: 156).

Penjatuhan pidana terhadap pelaku kejahatan merupakan suatu proses dalam penyelesaian perkara pidana dan sebagai akibat hukum yang harus diterima oleh seseorang yang telah melakukan tindak pidana. Akibat hukum itu umumnya berupa hukuman pidana (Sianturi, 1996: 34). Di satu sisi, penjatuhan hukuman ditunjukan untuk memperbaiki tabiat terpidana dan di sisi lain penjatuhan hukuman itu juga dimaksudkan untuk pencegahan bagi masyarakat dari kemungkinan berbuat yang serupa (Mertha, 2014: 28). Namun dalam kejahatan korupsi untuk penjeraan terhadap pelaku 
kejahatannya masih sangat sulit, ini dibuktikan dengan masih maraknya kasus-kasus korupsi. Maka dari, itu diperlukan sebuah formulasi baru dalam sistem pemidanaan terhadap pelaku tindak pidana korupsi, bukan hanya dengan satu jenis sanksi yaitu sanksi pidana namun juga harus menggunakan sanksi yang bersifat preventif dan menjerakan seperti sanksi tindakan.

Dari permasalahan tentang sistem pemidanaan terhadap pelaku tindak pidana korupsi tersebut, maka dapat dirumuskan 2 (dua) permasalahan yaitu: 1) Bagaimana pengaturan tindak pidana terhadap pelaku tindak pidana korupsi? 2) Bagaimana sistem pemidanaan terhadap pelaku tindak pidana korupsi? Adapun tujuan kajian ini ialah untuk memahami pengaturan tindak pidana bagi pelaku kejahatan pidana korupsi dan untuk memahami sistem pemidanaan terhadap pelaku kejahatan pidana korupsi.

\section{METODE PENELITIAN}

Tipe Penelitian yang dipergunakan dalam pembuatan karya ilmiah ini adalah Tipe Penelitian Hukum Normatif ialah penelitian kepustakaan sedangkan Pendekatan masalah yang digunakan adalah Pendekatan Perundang-undangan dan pendekatan konseptual. Adapun Sumber hukum yang dipergunakan bersumber dari penelitian kepustakaan yaitu, materi hukum primer yakni materi hukum dari peraturan perundang-undangan dan materi hukum sekunder diperoleh dari pengkajian kepustakaan yaitu dari buku-buku dan hasil penelitian ahli hukum.

Teknik pengumpulan bahan hukum yaitu dengan mengkaji peraturan perundang-undangan tentang pemidanaan terhadap pelaku tindak pidana korupsi dan dengan menggunakan catatan kecil dari buku dan literatur yang ada hubungannya dengan persoalan yang dibahas. Analisis materi hukum yang dipergunakan adalah dengan cara deskriptif analisis yaitu mengadakan analisis dengan mendeskripsikan atau menjelaskan peraturan-peraturan yang ada, buku-buku kepustakaan dan literatur lainnya yang berkaitan dengan bahan, sehingga dapat diambil suatu kesimpulan.

\section{HASIL DAN PEMBAHASAN}

\section{Pengaturan Tindak Pidana terhadap Pelaku Tindak Pidana Korupsi}

Kejahatan korupsi adalah suatu tindakan yang bertentangan dengan hukum yang menggunakan suatu wewenang yang diberikan kepada dirinya guna mendapatkan untung bagi diri sendiri, orang lain ataupun kelompok dan menyebabkan perekonomian negara menjadi rugi. Selain itu korupsi adalah tingkah laku individu yang buruk mepergunakan wewenang dalam jabatannya untuk mengambil keuntungan dan merugikan kepentingan umum. UU No. 31 Tahun 1999 jo. UU No. 20 Tahun 2001 mendefinisikan korupsi sebagai tindakan membuat untung diri sendiri, bukan diri sendiri termasuk badan hukum dengan cara melawan hukum baik dengan menyalahgunakan kekuasaan ataupun tanpa kekuasaan yang mengakibatkan kerugian keuangan negara. Korupsi mencakup perilaku buruk dari pejabat, politisi atau pegawai negeri dengan cara menyalahgunakan kekuasaan dan melanggar hukum membuat untung diri mereka (Arsyad, 2013: 5).

Subyek hukum kejahatan pidana korupsi adalah pegawai pemerintahan atau aparatur negara dan setiap orang termasuk korporasi. Pegawai pemerintahan atau aparatur negara adalah orang yang digaji dari suatu badan hukum atau korporasi yang menggunakan fasilitas ataupun modal dari negara. Sedangkan setiap orang termasuk korporasi disini bermakna bahwa setiap orang adalah tidak hanya terbatas pada suatu kelompok maupun profesi tertentu melainkan semua orang yang memenuhi rumusan dari suatu kejahatan korupsi dapat termasuk dalam kategori setiap orang. Dan korporasi disini dapat diartikan sebagai badan hukum ataupun bukan badan hukum yang berupa sekelompok orang atau kekayaan yang terorganisasi. Dalam kejahatan korupsi, korporasi dapat dikatakan sebagai pelaku kejahatan korupsi apabila dilakukan oleh orang-orang secara sendiri ataupun bersama-sama baik berdasarkan hubungan kerja ataupun hubungan lain.

Dalam UU No. 31 Tahun 1999 jo. UU No. 20 Tahun 2001 ada tujuh macam perbuatan yang dapat dikatakan Kejahatan Korupsi yaitu:

1. Tindak Pidana Murni Membuat Rugi Keuangan Negara adalah perbuatan tiap orang yang bermaksud membuat untung diri sendiri, bukan diri sendiri termasuk badan hukum secara melawan hukum dengan atau tanpa kewenangan yang menyebabkan kerugian negara. Tindak pidana ini diatur dalam Pasal 2, 3, dan 17 UU No. 31 Tahun 1999, Pasal 7 ayat (1) huruf a, huruf c, 7 ayat (2), 8, 9, 10 huruf a, 12 huruf i, dan 12A UU No. 20 Tahun 2001. 
2. Kejahatan Pidana Korupsi "Suap" adalah tindakan seseorang yang memberi ataupun memberi janji sesuatu pada pegawai pemerintahan atau aparatur negara untuk bertindak atau tidak bertindak sesuatu dan pada hakim untuk mempengaruhi putusannya. Tindak pidana ini diatur dalam Pasal 5 dan 17 UU No. 31 Tahun 1999 dan Pasal 6, 11, 12 huruf a, huruf b, huruf c, huruf d, dan 12A UU No. 20 Tahun 2001.

3. Tindak Pidana Korupsi "Pemerasan" adalah perbuatan pegawai negeri atau penyelenggara negara yang bermaksud menguntungkan diri sendiri atau orang lain dengan memaksa seseorang membayar atau memberikan sesuatu dan memotong pembayaran kepada pegawai negeri lain atau kas umum seolah-olah hal itu adalah utang. Tindak pidana ini diatur dalam Pasal 17 UU No. 31 Tahun 1999 dan Pasal 12 huruf e, huruf f, huruf g, dan 12A UU No. 20 Tahun 2001.

4. Tindak Pidana Korupsi "Penyerobotan" adalah tindakan pegawai negeri sipil atau penyelenggara negara menggunakan tanah yang diatasnya terdapat hak pakai pada saat menjalankan tugas dan merugikan orang yang berhak. Tindak pidana ini diatur dalam Pasal 17 UU No. 31 Tahun 1999 dan Pasal 12 Huruf h UU No. 20 Tahun 2001.

5. Tindak Pidana Korupsi "Gratifikasi" adalah perbuaatan setiap orang yang memberikan hadiah atau janji kepada pegawai negeri atas wewenang dari jabatanya. Tindak pidana ini diatur dalam Pasal 13 dan 17 UU No. 31 Tahun 1999 dan dalam Pasal 12 B dan 12 C UU No. 20 Tahun 2001.

6. Tindak Pidana Korupsi "Percobaan, Pembantuan, dan Pemufakatan" adalah perbuatan tiap orang yang melakukan percobaan, memberi bantuan atau kesepakatan jahat untuk melakukan korupsi dan pegawai pemerintah atau orang selain pegawai pemerintah yang menggelapkan, membiarkan atau membantu orang lain untuk menggelapkan uang atau surat berharga. Tindak pidana ini diatur dalam Pasal 15, 16, dan 17 UU No. 31 Tahun 1999 dan Pasal 7 Ayat (1) Huruf b, Huruf d, 8, 10 Huruf b, Huruf c UU No. 20 ahun 2001.

7. Tindak Pidana Korupsi "Lainnya" adalah perbuatan tiap orang yang merintangi, menghalangi atau menggagalkan secara langsung ataupun tidak langsung penyidikan, penuntutan dan pemeriksaan di persidangan serta tidak memberikan keterangan ataupun memberikan keterangan yang palsu dalam perkara korupsi. Perbuatan ini diatur dalam Pasal 21, 22, 23, dan 24 UU No. 31 Tahun 1999

\section{Sistem Pemidanaan terhadap Pelaku Tindak Pidana Korupsi}

Sistem memiliki pengertian suatu metode yang teratur dalam mencapai suatu tujuan. Sedangkan pemidanaan adalah penjatuhan sanksi terhadap seseorang yang telah melakukan suatu perbuatan yang melanggar aturan yang berlaku. Jadi sistem pemidanaan dapat diartikan sebagai suatu metode yang teratur dalam menjatuhkan suatu sanksi pidana terhadap seseorang yang melakukan perbuatan melanggar hukum atau atauran yang berlaku.

Sistem pemidanaan terhadap pelaku tindak pidana dapat dibagi menjadi 3 teori pemidanaan yaitu teori absolut yang memfokuskan pada unsur pembalasan atas tindak pidana yang dilakukan oleh si terpidana, teori relatif yang lebih berfokus pada upaya preventif agar masyarakat yang lain tidak melakukan kejahatan yang sama dan untuk merubah si terpidana agar menjadi orang yang lebih baik, dan teori gabungan yang mengkombinasikan antara unsur pembalasan dan unsur pencegahan sebagai satu kesatuan teori pemidanaan.

Dalam sistem pemidanaan terhadap pelaku tindak pidana korupsi yang paling relevan digunakan adalah teori gabungan karena dalam teori tersebut terdapat unsur pembalasan dan pencegahan yang bertujuan untuk memberikan efek jera dan sekaligus sebagai upaya pencegahan terhadap tindak pidana yang sama. Teori ini juga sesuai dengan konsep pemidanaan melalui Double Track System (Ramadhani dkk., 2012). Double Track System ialah suatu konsep pemidanaan melalui dua jalur yaitu sanksi pidana dan sanksi tindakan (Ramadhani dkk., 2012; Sinaga dkk., 2018; (Syakirin, 2018). Sanksi pidana bertujuan memberikan pembalasan dan efek jera kepada pelaku tindak pidana sedangkan sanksi tindakan berfokus pada usaha memberikan bantuan pada pelaku agar bisa berubah dan mencegah masyarakat lain melakukan kejahatan yang sama. Pada UU No. 31 Tahun 1999 jo. UU No. 20 Tahun 2001, konsep Double Track System adalah berupa penjatuhan pidana penjara dan denda. Pidana penjara merupakan "sanksi pidana" dalam konsep Double Track System 
karena pidana penjara merupakan perampasan kemerdekaan dan pembalasan terhadap kejahatan yang dilakukan oleh pelaku korupsi yang bertujuan agar adanya efek jera terhadap pelaku tersebut.

Sedangkan denda merupakan "sanksi tindakan" dalam konsep Double Track System karena denda merupakan perampasan keuntungan yang didapat dari kejahatan korupsi yang bertujuan untuk upaya pencegahan terhadap kejahatan yang sama dan sebagai upaya pengembalian kerugian keuangan negara.

\section{SIMPULAN DAN SARAN}

\section{Simpulan}

Dalam UU No. 31 Tahun 1999 jo. UU No. 20 Tahun 2001 ada tujuh macam perbuatan yang dapat dikatakan Kejahatan Korupsi yaitu:

1. Kejahatan Murni Merugikan Keuangan yang diatur dalam Pasal 2, 3, dan 17 (UU No. 31 Tahun 1999) dan Pasal 7 Ayat (1) Huruf a, Huruf c, 7 ayat (2), 8, 9, 10 Huruf a, 12 Huruf i, dan 12A (UU No. 20 Tahun 2001).

2. Tindak Pidana Korupsi "Suap" yang diatur dalam Pasal 5, 17 (UU No. 31 Tahun 1999) dan 6, 11, 12 Huruf a, Huruf b, Huruf c, Huruf d, dan 12A (UU No. 20 Tahun 2001).

3. Tindak Pidana Korupsi "Pemerasan" yang diatur dalam Pasal 17 (UU No. 31 Tahun 1999) dan Pasal 12 Huruf e, Huruf f, Huruf g, dan 12A (UU No. 20 Tahun 2001).

4. Tindak Pidana Korupsi "Penyerobotan" yang diatur dalam Pasal 17 (UU No. 31 Tahun 1999) dan Pasal 12 Huruf h (UU No. 20 Tahun 2001).

5. Tindak Pidana Korupsi "Gratifikasi" yang diatur dalam Pasal 13 dan 17 (UU No. 31 Tahun 1999) dan Pasal 12 B dan 12 C (UU No. 20 Tahun 2001).

6. Tindak Pidana Korupsi "Percobaan, Pembantuan, dan Pemufakatan" yang diatur dalam Pasal 15, 16, 17 (UU No. 31 Tahun 1999) dan Pasal 7 Ayat (1) Huruf b, Huruf d, 8, 10 Huruf b, Huruf c (UU No. 20 Tahun 2001).

7. Tindak Pidana Korupsi "Lainnya" yang diatur dalam Pasal 21, 22, 23, 24 (UU No. 31 Tahun 1999).

Sistem pemidanaan terhadap pelaku tindak pidana dapat dibagi menjadi 3 teori pemidanaan yaitu teori absolut yang menekan pada unsur pembalasan atas tindak pidana yang dilakukan oleh si terpidana, teori relatif yang lebih menekankan pada upaya preventif sebagai pencegahan terhadap masyarakat agar tidak melakukan kejahatan yang sama dan untuk merubah si terpidana agar menjadi orang yang lebih baik, dan teori gabungan yang mengkombinasi antara unsur pembalasan dan unsur pencegahan sebagai satu kesatuan teori pemidanaan (Usman, 2011; Soponyono, 2012; Kansil, 2014). Dalam sistem pemidanaan terhadap pelaku tindak pidana korupsi yang paling relevan digunakan adalah teori gabungan karena dalam teori tersebut terdapat unsur pembalasan dan pencegahan yang bertujuan untuk memberikan efek jera dan sekaligus sebagai upaya pencegahan terhadap tindak pidana yang sama. Teori tersebut juga sesuai dengan konsep Double Track System yang menggunakan dua jalur dalam penjatuhan sanksinya yaitu sanksi pidana dan sanksi tindakan. Dalam UU No. 31 Tahun 1999 jo. UU No. 20 Tahun 2001 konsep Double Track System adalah berupa penjatuhan pidana penjara dan denda.

\section{Saran}

Pengaturan tindak pidana korupsi dalam UU No. 31 Tahun 1999 jo. UU No. 20 Tahun 2001 harus lebih memperberat hukuman kepada pelaku Kejahatan korupsi baik pidana penjara maupun denda karena pidana penjara dan denda merupakan bentuk pemidanaan dua jalur (Double Track System) yang cocok digunakan sebagai upaya pemberian efek jera bagi pelaku tindak pidana korupsi dan juga sebagai upaya pencegahan terhadap terjadinya kejahatan korupsi.

Sistem pemidanaan terhadap pelaku kejahatan korupsi masih belum sempurna sepenuhnya ini dibuktikan dari terus meningkatnya tindak pidana korupsi tersebut dari waktu ke waktu. Maka dari itu sistem pemidanaan terhadap pelaku tindak pidana korupsi masih perlu dibenahi baik dari segi aturan yang mengatur maupun dari penegak hukum yang melaksanakan pemidanaan tersebut agar kedepannya sistem pemidanaan bisa menjadi alat penjeraan terhadap pelaku kejahatan korupsi maupun sebagai pencegah agar masyarakat tidak melakukan kejahatan korupsi. 


\section{DAFTAR PUSTAKA}

Arsyad, J. H. (2013). Korupsi dalam Perspektif HAN (Hukum Administrasi Negara). Sinar Grafika.

Kansil, F. (2014). Sanksi Pidana dalam Sistem Pemidanaan Menurut KUHP dan di Luar KUHP. Lex Crimen, 3(3), 26-34.

Mertha, I. K. (2014). Efek Jera Pemiskinan Koruptor dan Sanksi Pidana. Udayana University Press.

Ramadhani, G. S., Arief, B. N., \& Purwoto. (2012). Sistem Pidana dan Tindakan "Double Track System" dalam Hukum Pidana di Indonesia. Diponegoro Review, 1(4), 1-9.

Sianturi, S. R. (1996). Azas-Azas Hukum Pidana. PT Rineka Cipta.

Sinaga, M. N., Hukum, F., \& Simalungun, U. (2018). Ide Dasar Double Track System: Sanksi Pidana dan Tindakan Sebagai Sistem Pemidanaan terhadap Pelaku Kejahatan Penyalahgunaan Narkotika. Jurnal Penelitian Pendidkan Sosial Humaniora, 3(1), 337-345.

Soponyono, E. (2012). Kebijakan Perumusan Sistem Pemidanaan yang Berorientasi pada Korban. Masalah-Masalah Hukum, 41(1), 29-41.

Syakirin, A. (2018). Formulasi/Model Sistem Pemindanaan Anak di Indonesia. Mimbar Yustitia, 2(2), $1689-1699$.

Syamsuddin, A. (2011). Tindak Pidana Khusus. Sinar Grafika.

Usman. (2011). Analisis Perkembangan Teori Hukum Pidana. Jurnal Ilmu Hukum, 2(1), 62-78. 